\title{
Tutor Support of the Educational Process to Increase the University Students' Satisfaction with the Quality of Education
}

\author{
Marina A. Konovalova 1[ORCID 0000-0001-6378-2781], \\ Ksenia A. Rudenko ${ }^{1 *[O R C I D ~ 0000-0002-4617-5370] ~}$
}

\author{
${ }^{1}$ Yaroslav-the-Wise Novgorod State University, Veliky Novgorod, Russia \\ selix13@yandex.ru
}

\begin{abstract}
In the article, the authors examine the dependence of the degree of student satisfaction with the quality of education on the availability of tutor support for the work of project groups of first-year students of Yaroslavthe-Wise Novgorod State University. The influence of tutor support on the formation of subjectivity among students is analyzed within the framework of the management model at the university. In the course of the study, it was determined that mastering the tools for determining individual educational trajectories and reflecting them potentially affects the awareness of the value of the education received, and, as a result, the growth of satisfaction with education at the university. This process is seen as a way to solve the problem of applicants choosing specialties in which they do not intend to find employment in the future. The methodological basis of the study was the competency-based and subject-object approaches in education. The following methods were used in the study: analysis of the literature on the research problems; experiment; one-way analysis of variance, testing of hypotheses by the Fisher criterion, survey (questionnaire), methodology for assessing the stages of formation of subjectivity. Changes in the subjectivity of students accompanied by a tutor as part of project teams in the first year of study at the university have been quantitatively and statistically proven. The principal result of the study is the establishment of the fact that if university students have or increase tutor support: awareness of educational processes at the university, craving for self-education, motivation to determine educational and career trajectories, expert significance, motivation to create a personal brand. Positive changes were noted in the assessment of the usefulness of the knowledge gained by students after three months of regular classes. This fact ultimately increases satisfaction with the quality of education.
\end{abstract}

Keywords: Tutor, tutor student, tutor support, satisfaction with education, individual educational trajectory, consciousness, subjectivity

\section{INTRODUCTION}

The process of forming the educational environment in universities should be focused primarily on the needs of the society in which they operate. This process must be adaptive to the new conditions of a rapidly changing environment. The current state of the system of higher education in Russia does not meet the requirements of an innovative economy. This is also reflected in the fact that up to $60 \%$ of university graduates do not work in their specialty [1]. The received diploma of higher education does not guarantee successful employment and career growth. Universities should focus on preparing graduates who are competitive in the labor market, this is impossible if the students themselves do not take responsibility for their own actions and choices, this refers to subjective characteristics [2] and traditionally remains without due attention in the framework of classical education.

Although soft skills are in high demand in the labor market, they are currently underrepresented in higher education. Soft skills require a different new educational process than in the case of hard skills [3].

Universities that follow the path of progress, instead of the process of passive listening to 
indisputable authorities, offer students the active formation of the concept of their own development and professional self-identification through new formats of training sessions, through the interaction of subjects of education [4, 5]. One of the key tasks of increasing the success of a student is the organization of a competently accompanied process of involving him in self-development [6, 7]. This increases the motivation for learning and, as a result, has a positive effect on the quality of education, which is confirmed by many studies $[7,8]$.

Moving away from the usual formats requires dynamic changes in educational work, which dictates high requirements for knowledge and skills [9], not only for those that researchers have, but also for university professors. The problem is that a specialist is needed to work with a student as a person to form him as a subject [10], the factors of problematization can be situations of high uncertainty and the need to make a choice in the educational program [11]. A tutor can and should become such a specialist, but this profession in universities is mainly at the stage of either an experimental model or a highly specialized model for the tasks of a particular university.

If students' choice of a specialty is closely related to their interests, and it is in this area that the tutor's activity lies, then they are more likely to adhere to this specialty in the future [12]. They will have an increased interest in learning, in achieving better results, and they will be more satisfied with the quality of education.

Based on the analysis of the literature on the topic under study, it can be stated that most of the above researchers agree that the level of student subjectivity positively correlates with the level of satisfaction with the education received. Recently, the number of publications on tutor support in Russian universities and its impact on subjectivity has been growing. At the same time, there is no information on whether there is a dependence of the degree of satisfaction of students with education on the availability of tutor support. The peculiarity and novelty of the study lies in the fact that the authors consider tutor support for the collective work of students - work in teams, while individual tutor support is traditionally analyzed.

The present study tests the hypothesis that through tutor support of the work of project student teams in the first year of study at a university within the framework of the discipline "Project Activity Principles" (hereinafter - PAP) in the model of Yaroslav-the-Wise Novgorod State University (further in the text it will be referred to as NovSU) [13] the student develops a subjective attitude to the educational process, the student's conscious attitude is transferred to the definition of his educational trajectory in the process of studying at the University and career moves into the future. The student understands where and how he can apply the knowledge and skills acquired at the university for the benefit of himself and others, he begins to invest his time and energy in the learning process, and this activity contributes to his awareness of the value of the education received and, as a result, contributes to an increase in satisfaction with the quality of education at the chosen university. The above information indicates the relevance of the presented study.

\section{MATERIALS AND METHODS}

The purpose of the research is to study the impact of systematic tutor support of students' team work on their perception of the value of education received at NovSU, and, as a result, on satisfaction with the quality of education received.

To achieve this purpose, the following research objectives were set:

- to determine the scope of tutor support for project teams of $1^{\text {st }}$ year students of NovSU;

- to conduct a survey of students to determine: the impact of tutor support on changing the subjectivity of students; the presence of problems with the conscious attitude of applicants to the choice of specialty when choosing a faculty and problems with understanding the future career path; the level of students' assessment of the usefulness of the knowledge gained at the university and satisfaction with the quality of education; awareness and evaluation of the role of the tutor in the educational process;

- to examine and to interpret the polls results.

The methodological basis of the study was the competency-based and subject-object approaches in education. The following methods were used: analysis of the literature on the problems of the topic under study; experiment; survey method (questionnaire). It is the questionnaire, as a key tool for Customer Development, that allows you to test the hypothesis about the student as a consumer of the educational program and most correctly set up tutor support to achieve the goal.

The study of the influence of tutor support on the 
change in the subjectivity of students, carried out according to the methodology for assessing the stages of the formation of subjectivity E.V. Drozdova [14], based on the interpretation of the scales of the stage of formation of subjectivity, proposed by V.I. Panov. NovSU first-year students answered the questionnaire before the inclusion of tutors in project teams (October 2020, 454 respondents), and then at the end of the semester (December 2020, 86 respondents). The tutor coverage was incomplete, therefore, as a result, the respondents were divided into a control group (without tutor support) and an experimental group (with tutor support). Thus, the comparison was carried out both by the group-period method and by the group-analog method. The results were statistically processed using one-way analysis of variance and Fisher's test.

In October-December 2021, a survey was conducted of 186 first-year full-time students in various social and humanitarian areas of training. The main questions were aimed at finding out if the students have the problems listed below:

- the problem with a conscious attitude to the choice of specialty when choosing a university and faculty;

- problems with students understanding where and how they will apply their knowledge and experience for the benefit of themselves and others;

- the problem with determining one's individual educational trajectory and career growth.

The level of students' assessment of the usefulness of the acquired knowledge and the level of satisfaction with the quality of education were also revealed. And the dynamics of understanding the role of the tutor in accompanying the educational process was monitored.

\section{RESULTS}

The model of tutor support at NovSU is successive in relation to the educational intensive "University of National Technology Initiative 20.35 at NovSU" in 2018. Tutors have become a key component of the implementation of the subjectoriented technology of individualization of the educational process. This technology includes: the development of reflexivity and internal motivation and professional orientation, as well as the formation of the student's subjective position. In 2019, the model was scaled up to organize support for 140 teams, as a result of which the tutoring practice of NovSU was certified by the Interregional Association of Tutors in 2020.

The model of experimental tutor support was applied in the 2020-2021 academic year. Teams with and without a tutor were formed among first-year students at the university. A comparison was made of the level of development of the subjectivity of students in different types of teams at the beginning and end of the semester, the results are presented in Table 1 .

Table 1. The level of subjectivity of first-year students at NovSU in the autumn semester of 2020

\begin{tabular}{|c|c|c|c|}
\hline \multirow[b]{2}{*}{$\begin{array}{c}\text { Level of } \\
\text { Subjectivity }\end{array}$} & \multirow[b]{2}{*}{$\begin{array}{l}\text { Beginning } \\
\text { of Semester }\end{array}$} & \multicolumn{2}{|c|}{ End of the Semester } \\
\hline & & $\begin{array}{l}\text { without } \\
\text { tutor } \\
\text { support }\end{array}$ & $\begin{array}{l}\text { with tutor } \\
\text { support }\end{array}$ \\
\hline Observer & 34.5 & 29.3 & 34.9 \\
\hline Apprentice & 26.7 & 26.4 & 30.8 \\
\hline Learner & 31.9 & 30.2 & 36.1 \\
\hline Master & 36.7 & 33.2 & 39.8 \\
\hline Expert & 34.7 & 31.4 & 38.9 \\
\hline Creator & 38.1 & 33.6 & 39.6 \\
\hline $\begin{array}{l}\text { with ranking } \\
\text { assignment }\end{array}$ & 122.1 & 110.7 & 132.7 \\
\hline
\end{tabular}

Source: Compiled by the authors

The intragroup variance is almost 4 times higher than the intergroup one when checking for different options: students at the beginning and at the end of the semester without tutor support, as well as students at the end of the semester with and without tutor support. This fact testifies to the high heterogeneity of students in relation to the manifestation of subjectivity in any options for their tutor support in project and educational activities and confirms the multiplicity of factors affecting self-determination.

Comparison of groups of students before and after tutor support is indicative, the influence of tutor support reaches the estimated rate of $53 \%$. A statistically significant effect is confirmed by Fisher's test of 11.12 , with its critical value of 4.96 for the number of degrees of freedom represented $(\mathrm{p}=0.05)$.

A significant achievement in the process of forming the position of a tutor at NovSU should be considered the introduction in the 2021-2022 academic year of a full-time tutor with the appropriate work experience. In the structure of the new structural subdivision of NovSU - the Center "School of Project-Based Learning", the official position of "tutor" appeared. A form of organization for the tutor of the possibility of independent choice 
of means, methods of working with students and the possibility of monitoring the current state of students with tutor support.

The management framework fulfills this need by supporting the exchange of information using modern technologies. At NovSU, the global framework is to maintain the position of a tutor, within which focuses of the overall work and individual key tutors are established. There are a number of ready-made tools for the job. In addition, the tutor has the right to choose any other instrument, distribute the ratio of time and effort in each lesson. The collection of information from tutors and from students with tutor support is organized to increase the degree of flexibility of the given framework and ensure the possibility of making operational management decisions.

The peculiarity of the individualization of the educational trajectories of students at NovSU is that it is carried out in group classes. Textbooks are related to the logic of project activities. On the one hand, this logic stimulates the problematization of educational deficits (soft skills, self skills and hard skills at the final stage) in the face of uncertainty created by the need to work in a team consisting of students from different areas of training for the institute, different specialties, unfamiliar to most school graduates. logic. On the other hand, project activity is a resource (a resource of team interaction and an educational resource).

A survey conducted in October-December 2021 among first-year students of NovSU confirmed the existence of problems with the conscious attitude of applicants to the choice of specialty and with an understanding of where and how they will apply their knowledge and experience in the future.

Only slightly more than half of the students surveyed (social and humanitarian specialties) have a firm intention to work in their chosen specialties (Figure 1).

The rest of the students either already plan to learn another profession, or do not understand at all what they would like to be in their profession in the future and are in search. In the case of some specialties - for example, medical workers, programmers - the consciousness of choosing a future student is high. These specialties are not chosen without the intention to work in their direction in the future. As for students of humanitarian faculties, according to the survey, the reasons for choosing most often are: the choice of parents; the choice of any university (where there are enough passing scores); choice for a group of friends.

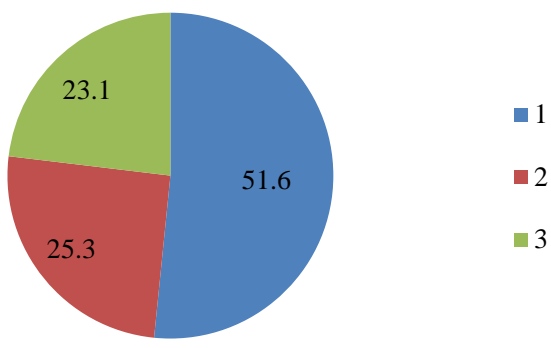

1 - students who want to work in their specialties

2 - students who want to work in other specialties

3 - students who don't know what specialties they want to work in

Figure 1. Students' intentions (first year of study at NovSU, 2021, \%)

Source: Compiled by the authors

If students do not understand where and how they will apply their education for the benefit of themselves and others, they do not realize its value, and it is obvious that this will negatively affect student satisfaction with the quality of education.

At the beginning of tutor support for students in 2021 at NovSU, the level of usefulness of the knowledge gained at the university, according to the respondents themselves, is quite low, on average $40 \%$. Subsequently, by the end of the semester, the opinion of students changed positively - up to $50 \%$ on average.

Many students are still in search of their interests, ways of their professional development, they lack a culture of learning, they do not realize the importance of determining the educational trajectory (Figure 2).

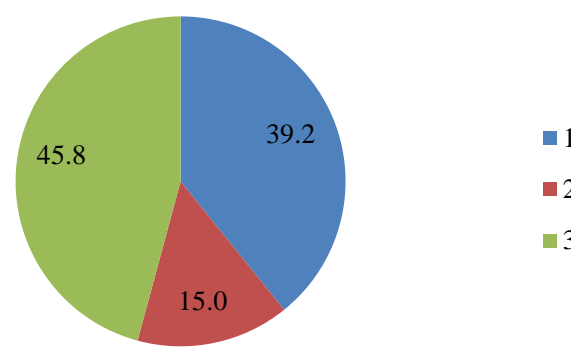

1 - students who understand in which area to educate themselves and are already doing it

2 - students who intend to study exclusively what is given as part of the educational programs of the university, and do not consider the option of additional self-education

3 - students who would like to advance in self-education, but don't know what to do

Figure 2. The attitude of students towards selfeducation (the first year of study at NovSU, 2021, $\%)$

Source: Compiled by the authors 
At the beginning of the semester, only every twentieth student had an idea about the role of a tutor in the process of accompanying the educational process. After three months of tutor support, students got the opportunity to form their own idea on this issue and, according to the results of the survey, tutor support helps them realize their interests, preferences in personal, professional, and scientific fields.

\section{DISCUSSION}

The tutor support management structure preserves the cost indicators of tutor activity and adapts it to the specific conditions and requirements of the university, which allows you to quickly respond to the needs of a changing economy and train in-demand personnel.

This study confirms that tutor support for determining the individual educational trajectory of first-year students at the university as part of project teams contributes to the growth of subjectivity (the influence of the tutor reaches 53\%), involvement and motivation.

Tutoring of the educational process at Novgorod State University entails the emergence and / or increase in the self-awareness of students in the process of studying at a university, the desire for self-education, motivation to determine the educational and career trajectory, professionalism, motivation to create a personal brand. All these facts contribute to the subsequent increase in student success in the labor market, its readiness for changes in the modern world and, as a result, this has a positive effect on student satisfaction with the quality of the education received.

\section{CONCLUSION}

The question of the role of tutor support of the educational process is of great importance for those who make managerial decisions in universities. If the management understands that this process has a positive effect on the human capital created by the university, that it can improve the quality of education offered by the university, then it becomes important to provide this service to students, to establish interaction between students and tutor as a part of the education program.

The analysis of the results allows us to make two contributions to research on the topic of tutor support in universities. Firstly, it demonstrates the dependence of the degree of student satisfaction with learning on the availability of tutor support, demonstrates the importance of tutor support for the educational process at the university to increase student satisfaction with the quality of education by increasing the subjectivity of students and their awareness of the usefulness of the knowledge they receive. Secondly, studies prove the presence of a statistically significant increase in the subjectivity of students in project teams with tutor support in the first year of study at a university.

\section{AUTHORS' CONTRIBUTIONS}

Marina A. Konovalova was the head of tutor support at NovSU in 2018, and since November 2020 she has been a tutor for project student teams and a tutor supervisor. In the course of this study, she completed: methodological developments in the field of the tutor support model, measuring the subjectivity of students in the conditions of tutor support and without it, statistical processing and interpretation of the results of this experiment. Ksenia A. Rudenko, acting tutor of NovSU: provided tutor support to teams of freshmen in the framework of project activities; the students' understanding of the role of a tutor in the educational process was studied; data were collected to determine whether students have problems with a conscious attitude to the choice of specialty when choosing a university and faculty and with an understanding of their future career path; the issue of students' assessment of the usefulness of the knowledge gained at the university and satisfaction with the quality of education has been worked out.

\section{REFERENCES}

[1] S.A. Belyakov, T.L. Klyachko, E.A. Polushkina, "Secondary vocational education: state and development forecast", RANEPA, 2018, pp. 1-48. (In Russ.).

[2] G.F. Shafranov-Kutsev, G.Z. Efimova, "Moral aspect of young people's subjective competitiveness", Economic and Social Changes: Facts, Trends, Forecast, 2020, vol. 13(2), pp. 186-200. DOI: 10.15838/esc.2020.2.68.12

[3] T. Bolli, K. Caves, M.E. Oswald-Egg, "Valuable Experience: How University Internships Affect Graduates' Income”, Research in Higher Education, 2021, vol. 62(8), pp. 1198-1247. DOI: 10.1007/s11162-02109637-9 
[4] L.V. Vlasenko, I.A. Ivanova, V.N. Pulyaeva, "The academic motivation of generation $\mathrm{z}$ : value-oriented and cognitive aspects", International journal of applied exercise physiology, 2019, vol. 8(2-1), pp. 1023-1031.

[5] S.M. Fazal-E-Hasan, G. Mortimer, I. Lings, H. Sekhon, K. Howell, "Managing relationships: insights from a student gratitude model", Research in Higher Education, 2021, vol. 62(1), pp. 98-119. DOI: 10.1007/s11162019-09576-6

[6] H. Coates, K.E. Matthews, "Frontier perspectives and insights into higher education student success", Higher Education Research and Development, 2018, vol. 37(5), pp. 903907. DOI: $10.1080 / 07294360.2018 .1474539$

[7] C. Donaldson, J. Villagrasa, F. Sánchez, "Learner profile mapping: Stimulating autonomous motivation in entrepreneurship education", Industry and Higher Education, 2021. DOI: $10.1177 / 09504222211012322$

[8] C. Baumann, M. Harvey, "What is unique about high performing students? Exploring personality, motivation and competitiveness", Assessment and evaluation in higher education, 2021. DOI: $10.1080 / 02602938.2020 .1870930$

[9] Z. Anikina, L. Goncharova, A. Evseeva, "Constructing academic identity in the changing Russian higher education context: preliminary perspectives", Higher Education Research \& Development, 2020, vol. 39(5), pp. 855-868. DOI: $10.1080 / 07294360.2019 .1704690$

[10] V.R. Imakaev, “Inculation” of objectivity. Experience of implementation of the project "tutor's support of personnels" in the Perm State National Research University ["Privivka" sub'yektnosti. Opyt realizatsii proyekta "t'yutorskoye soprovozhdeniye pervokursnikov" v Permskom gosudarstvennom natsional'nom issledovatel'skom universitete], In book:
Formation of the tutor model of a modern university in Russia [Stanovleniye t'yutorskoy modeli sovremennogo universiteta $\mathrm{v}$ Rossii], 2019, pp. 62-96. (In Russ.).

[11] N.N. Krasovskaya, "Model of tutoring support for the Liberal Arts educational program at the Russian Academy of National Economy and Public Administration under the President of the Russian Federation / RANEPA" [Model' t'yutorskogo soprovozhdeniya obrazovatel'noy programmy Liberal Arts v Rossiyskoy Akademii Narodnogo Khozyaystva i Gosudarstvennoy Sluzhby pri Prezidente Rossiyskoy Federatsii / RANKhiGS], In book: Formation of the tutor model of a modern university in Russia [Stanovleniye t'yutorskoy modeli sovremennogo universiteta v Rossii], 2019, pp. 96-110. (In Russ.).

[12] J.L. Moore, T.M. Cruce, "The Impact of an Interest-Major Fit Signal on College Major Certainty", Research in Higher Education, 2020, vol. 61(3), pp. 383-407. DOI: 10.1007/s11162019-09560-0

[13]M. Konovalova, "Tutor support of project activities during their skailing up at the university", European Proceedings of Social and Behavioural Sciences EpSBS, ISPC, European Publisher, 2021, pp. 1507-1514. DOI: 10.15405/epsbs.2021.05.02.191

[14]E.V. Drozdova, "Method of evaluation stages of the formation of the subjectivity of civil servants", Bulletin of the Samara Academy for the Humanities. A Series of Psychology, 2017, vol. 1(21), pp. 119-132. (In Russ.)

[15]P.S. Avetisyan, N.M. Gevorgyan, "Free educational environment as the basis of human capital and relationships between social sectors", Economy of Region, 2020, vol. 16(2), pp. 494-506. (In Russ.). DOI: 10.17059/2020-212 